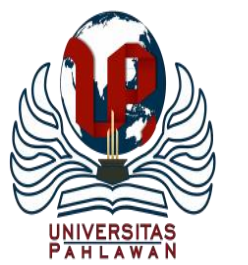

Edukatif : Jurnal Ilmu Pendidikan Volume 3 Nomor 3 Tahun 2021 Halm 770 -776 EDUKATIF: JURNAL ILMU PENDIDIKAN

Research \& Learning in Education

https:/ledukatif.org/index.php/edukatif/index

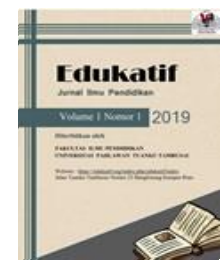

\title{
Model Discovery Learning Berbantuan Media Audio Visual untuk Meningkatkan Keaktifan dan Hasil Belajar IPA Siswa Sekolah Dasar
}

\author{
Lysa Amorita Rachmawati $^{1 凶}$, Henny Dewi Koeswanti ${ }^{2}$ Tri Sadono $^{3}$ \\ Universitas Kristen Satya Wacana, Indonesia ${ }^{1,2,3}$ \\ E-mail : 952020512@ student.uksw.edu ${ }^{1}, \underline{\text { hennykoeswanti@ gmail.com }}^{2}$, sadonotri@gmail.com $^{3}$
}

\begin{abstract}
Abstrak
Sekolah di masa pandemik merupakan tantangan bagi guru untuk tetap melaksanakan pembelajaran dengan tetap menjalankan social distancing. Belajar dari rumah merupakan salah satu alternatif dalam mewujudkannya. Model serta media pembelajaran turut berperan dalam meningkatkan hasil belajar dan juga keaktifan siswa. Tujuan penelitian ini adalah untuk meningkatkan keaktifan dan hasil belajar siswa melalui penerapan pembelajaran dengan model Discovery learning berbantuan media audio visual berupa video pembelajaran. Model Discovery learning adalah merupakan pembelajaran yang memberikan pengalaman langsung kepada siswa melalui praktek atau percobaan. Jenis penelitian ini yaitu Penelitian Tindakan Kelas (PTK) dengan model dari Kemmis dan Mc.Taggart yang setiap siklusnya terdiri dari (1) perencanaan, (2) pelaksanaan, (3) pengamatan, dan (4) refleksi. Subjek penelitian yaitu siswa kelas IV SDN 2 Penadaran, dengan jumlah 26 orang. Teknik pengumpulan data dilaksanakan dengan wawancara, observasi dan tes melalui LKPD, sedangkan teknik analisis data menggunakan model interatif yang terdiri dari reduksi data, penyajian data, dan verivikasi (penarikan kesimpulan). Hasil penelitian diperoleh, keaktifan dan hasil belajar siswa kelas IV tema 7 subtema 1 dan 2 pada pembelajaran meningkat dengan menggunakan model Discovery Learning menggunakan media audio visual terlihat dari prosentase keaktifan siswa yaitu: pada tes awal 34\%, hasil siklus I meningkat menjadi 69\%, dan mengalami peningkatan pada tes siklus II menjadi $84 \%$. Prosentase ketuntasan hasil belajar siswa pada tes awal $23 \%$, siklus I meningkat menjadi 57\%, dan mengalami peningkatan pada siklus II yaitu 84,6\%. Dapat disimpulkan discovery learning dan media audiovisual dapat meningkatkan kekatifan dan hasil belajar siswa sekolah dasar.
\end{abstract}

Kata Kunci: Discovery Learning, Keaktifan, Hasil Belajar.

\begin{abstract}
Schools during a pandemic are a challenge for teachers to continue to carry out learning while still carrying out social distancing. Learning from home is an alternative in making it happen. Learning models and media play a role in improving learning outcomes and also student activity. The purpose of this study was to increase student activity and learning outcomes through the application of learning with the Discovery learning model assisted by audio-visual media in the form of instructional videos. Discovery learning model is learning that provides direct experience to students through practice or experiment. The type of this research is Classroom Action Research (PTK) with a model from Kemmis and Mc.Taggart which each cycle consists of (1) planning, (2) implementation, (3) observation, and (4) reflection. The research subjects were the fourth grade students of SDN 2 Penadari, with a total of 26 people. The data collection technique was carried out by interviewing, observing and testing through LKPD, while the data analysis technique used an interactive model consisting of data reduction, data presentation, and verification (drawing conclusions). The research results obtained, the activeness and learning outcomes of fourth grade students with theme 7 sub-themes 1 and 2 in learning increased by using the Discovery Learning model using audio-visual media seen from the percentage of student activeness, namely: in the initial test 34\%, the results of the first cycle increased to 69\%, and an increase in the test cycle II to $84 \%$. The percentage of student learning outcomes completeness on the initial test was $23 \%$, the first cycle increased to $57 \%$, and an increase in the second cycle was $84.6 \%$. It can be concluded, Discovery learning and audiovisual media can improve the creativity and learning outcomes of elementary school students.
\end{abstract}

Copyright (c) 2021 Lysa Amorita Rachmawati, Henny Dewi Koeswanti, Tri Sadono

$\triangle$ Corresponding author

Email :952020512@student.uksw.edu

DOI : https://doi.org/10.31004/edukatif.v3i3.394

ISSN 2656-8063 (Media Cetak)

ISSN 2656-8071 (Media Online)

Edukatif : Jurnal Ilmu Pendidikan Vol 3 No 3 Tahun 2021 p-ISSN 2656-8063 e-ISSN 2656-8071 
771 Model Discovery Learning Berbantuan Media Audio Visual untuk Meningkatkan Keaktifan dan Hasil Belajar IPA Siswa Sekolah Dasar - Lysa Amorita Rachmawati , Henny Dewi Koeswanti, Tri Sadono DOI: https://doi.org/10.31004/edukatif.v3i3.394

\section{PENDAHULUAN}

Usaha pemerintah dalam mewujudkan pendidikan di Indonesia yang menghasilkan sumber daya manusia terdidik dan cerdas dalam menjawab tantangan masa depan sejalan dengan fungsi dan tujuan pendidikan nasional pada Undang-Undang Nomor 20 Tahun 2003, yaitu mengembangkan kemampuan dan membentuk watak serta peradaban bangsa yang bermartabat dalam rangka mencerdaskan kehidupan bangsa, serta bertujuan untuk berkembangnya potensi peserta didik agar menjadi manusia yang beriman dan bertakwa kepada Tuhan Yang Maha Esa, berakhlak mulia, sehat, berilmu, cakap, kreatif, mandiri, dan menjadi warga negara yang demokratis serta bertanggung jawab.

Menurut (Shoimin, 2014), bagian dari tujuan pendidikan nasional yakni pembangunan sumber daya manusia yang mempunyai peranan yang sangat penting bagi kesuksesan dan kesinambungan pembangunan nasional. Peserta didik dalam sebuah pembelajaran harus mengalami sendiri apa yang dipelajarinya. Proses belajar tidak hanya sekedar menghafal. Peserta didik harus membangun dan mengembangkan pengetahuan dipikirannya sendiri tanpa harus dipaksa sehingga pembelajaran akan menjadi bermakna. Keberhasilan pendidikan dipengaruhi oleh beberapa faktor, diantaranya guru. Peranan guru bukanlah hanya menerangkan pelajaran di depan kelas. Peranan Guru yaitu sebagai fasilitator, motivator yang mendukung keterlibatan Peserta didik dalam mengikuti kegiatan pembelajaran.

Tahun 2020 dunia digemparkan dengan corona virus. Corona virus adalah keluarga besar virus yang menyebabkan penyakit mulai dari gejala ringan sampai berat (Dewi, 2020). Dunia menyebutkan bahwa wabah Corona Virus sebagai pandemik. Masa Pandemi Corona Virus 19 (covid 19) ini, membuat proses pembelajaran yang biasanya dilaksanakan dengan tatap muka di dalam ruang kelas, harus beralih cara dalam proses pembelajarannya. Maka, untuk mencegah penyebaran virus semakin meluas, banyak sekolah yang telah memutuskan untuk menghentikan kegiatan belajar mengajar di kelas dan menggantinya dengan pembelajaran daring. Pembelajaran daring dapat dijadikan solusi pembelajaran jarak jauh ketika terjadi bencana alam. Seperti yang terjadi saat ini ketika pemerintah menetapkan kebijakan social distancing (Yunitasari \& Hanifah, 2020).Guru harus memanfaatkan teknologi yang ada agar pembelajaran di masa covid dapat terlaksana (D. I. Pratiwi, 2021). Pemerintah Indonesia sendiri, melalui Kementerian Pendidikan dan Kebudayaan dan Kementerian Agama RI, menerapkan kebijakan belajar dan bekerja dari rumah mulai pertengahan Maret 2020. Namun, dikarenakan waktu yang mendadak dan kurangnya persiapan tentang adanya perubahan pola pembelajaran, masih banyak pengajar yang kebingungan dalam mengubah materi yang biasa diajarkan di ruang kelas untuk menjadi kelas daring. Menurut (S. I. Pratiwi et al., 2021) perubahan proses pembelajaran ini mengharuskan guru untuk berinovasi.

Berdasarkan kondisi di lapangan dari hasil observasi dan wawancara dengan guru kelas IV Sekolah Dasar Negeri 2 Penadaran menyatakan bahwa hasil belajar siswa pada masa belajar di rumah dibawah capaian KKM $\geq 64$. Hal ini ditunjukan oleh rata - rata nilai Ulangan Harian yakni 60. Dalam satu kelas terdapat 26 siswa hanya 10 siswa yang memperoleh nilai di atas KKM yang sudah ditetapkan. Sedangkan 16 siswa mendapatkan nilai di bawah KKM yang ditentukan. Persentase siswa yang mendapat nilai di atas 70 yaitu $35 \%$ sedangkan persentase siswa yang mendapat nilai di bawah 70 yaitu $65 \%$. Dari persentase yang telah diuraikan menunjukkan bahwa siswa yang tidak tuntas lebih banyak dibandingkan siswa yang tuntas. Selain itu guru kelas pun mengungkapkan bahwa hasil dari Ulangan Tengah Semester juga menunjukkan bahwa siswa yang mendapatkan nilai Ulangan Tengah Semester di bawah standar KKM yang sudah ditetapkan oleh guru. Dari 26 siswa kelas 4 terdapat 14 siswa yang mendapatkan nilai dibawah standar KKM. Dari 26 siswa hanya 48\% (13 siswa) yang sudah memenuhi KKM, sedangkan 52\% (14 siswa) belum memenuhi KKM.

Berdasarkan observasi di lapangan, hal ini terjadi yaitu karena masih ada 4 siswa yang belum dapat membaca dengan lancar sehingga tidak dapat memahami soal dengan benar, siswa hanya mendapatkan materi melalui penjelasan yang diberikan guru sesuai yang ada dibuku. Selain hasil belajar siswa yang masih 
dibawah KKM 64, sikap siswa dalam kegiatan belajar amat tidak baik karena ada beberapa siswa diantaranya: siswa tidak mengunpulkan tugas tepat waktu, siswa mengerjakan tugas dengan tidak sesuai arahan dari guru, siswa asyik bermain saat tugas harus dikumpulkan segera. Kondisi seperti ini yang terus menerus berlanjut, akan menyebabkan hasil belajar siswa kurang maksimal. Padahal, hasil belajar merupakan salah satu indikasi penting yang menunjukkan kualitas mutu Pendidikan (Isnaeni et al., 2021).

Pada pembelajaran online, peserta didik dapat menjadi kurang aktif dalam menyampaikan aspirasi dan tingkat pemahaman materi ajar tidak maksimal sehingga dapat mengakibatkan pembelajaran yang menjenuhkan. Seorang siswa yang mengalami kejenuhan dalam belajar akan memperoleh ketidakmajuan dalam pembelajaran seperti halnya pemahaman terhadap materi pembelajaran. Media pembelajaran yang digunakan guru masih dalam bentuk modul file PDF yang dikirimkan kepada siswa melalui Whatsapp Group. Oleh karena itu, diperlukan strategi yang tepat untuk meningkatkan pemahaman materi pembelajaran tematik khususnya muatan pelajaran IPA (Ilmu Pengetahuan Alam) melalui media pembelajaran audio visual yang disampaikan oleh guru kepada siswa secara daring (dalam jaringan) maupun luring (diluar jaringan).

Berdasarkan kenyataan diatas, permasalahan tersebut perlu dilakukan perbaikan dan dilakukan penelitian. Atas masalah yang yang ditemui tersebut guru melakukan penelitian tindakan kelas dengan menerapkan model discovery learning berbantuan media audio visual untuk meningkatkan keaktifan dan hasil belajar IPA pada siswa kelas IV SDN 2 Penadaran.

Belajar menurut paham konstruktivisme adalah bagaimana siswa mengkonstruksikan suatu konsep berdasarkan pengetahuan yang dimiliki sebelumnya dan peran guru hanya sebagai fasilitator untuk membantu siswa dalam menciptakan iklim belajar yang kondusif (Heruman, 2012). Oleh karena itu, guru perlu merancang pembelajaran yang dapat meningkatkan pemahaman konsep siswa terhadap suatu materi. Salah satu pembelajaran yang mementingkan adanya perolehan konsep adalah model Discovery Learning.

Menurut (Nindya, 2018) discovery learning adalah model pembelajaran yang dapat meningkatkan keaktifan dan hasil belajar siswa. Discovery Learning merupakan pembelajaran yang memberikan pengalaman langsung kepada siswa melalui praktek atau percobaan sehingga siswa akan menemukan sendiri informasi yang sedang diajarkan dan dapat menarik suatu kesimpulan dari informasi tersebut. Sehingga pemahaman suatu konsep informasi akan bertahan lama dikarenakan siswa menemukan sendiri informasi tersebut.

Diberbagai sekolah, guru disarankan untuk mengemas pembelajaran dengan strategi-strategi pembelajaran aktif. keaktifan adalah kegiatan yang menuntut siswa ikut terlibat langsung dalam proses pembelajaran. Dengan keterlibatan ini, secara logis akan menyebabkan mereka memperoleh pengalaman atau pengetahuan baru (Artini, 2016). Menurut (Nindya, 2018) keaktifan belajar adalah keterlibatan siswa secara aktif dalam proses pembelajaran. Keaktifan akan menciptakan situasi belajar yang aktif seperti siswa aktif bertanya, mempertanyakan dan mengemukakan pendapat. Sedangkan menurut (Annurahman, 2010) menyatakan keaktifan siswa dalam belajar merupakan persoalan penting dan mendasar yang harus dipahami, dan dikembangkan setiap guru dalam proses pembelajaran. Sehingga keaktifan siswa perlu digali dari potensipotensi yang mereka aktualisasikan melalui aktifitas untuk mencapai tujuan pembelajaran. Maka keaktifan siswa adalah proses belajar yang menjadikan siswa aktif secara fisik dan non fisik sehingga membuahkan hasil belajar yang optimal dengan mengoptimalkan potensi yang dimiliki peseta didik serta tercapainya tujuan pembelajaran.

Pemilihan media yang tepat akan mempermudah guru dalam menyampaikan materi dan mempermudah siswa dalam menerima materi. Sejalan dengan penelitian (Wahyuningtyas \& Sulasmono, 2020) guru yang menggunakan media saat pembelajaran dapat mempermudah siswa dalam memahamu materi pelajaran sehingga memperoleh hasil belajar yang memuaskan. Media pembelajaran menurut (Mawardi, 2014) menyatakan bahwa hakikatnya sesuatu yang dapat digunakan sebagai sarana untuk menyalurkan pesan dan informasi materi pembelajaran sehingga dalam diri siswa terjadi proses belajar dalam rangka mencapai tujuan. Menurut (Hamdani, 2011) media audio visual merupakan kombinasi audio dan visual atau bisa disebut 
pandang dengar. Audio visual akan menjadikan penyajian bahan ajar kepada siswa semakin lengkap dan optimal. Media audio visual dalam hal ini adalah melalui video pembelajaran. Perpaduan aplikasi zoom dengan penggunaan media video pembelajaran diharapkan dapat menunjang pembelajaran daring agar lebih efektif. Pembelajaran muatan pelajaran IPA kelas IV materi tentang Gaya listrik statis dan dinamis lebih diarahkan menggunakan media audio visual yang mendorong siswa belajar aktif, baik secara fisik, sosial, maupun psikis.

Berdasarkan uraian di atas, penulis penelitian sebelumnya terkait pembelajaran di masa pandemik yang dituliskan oleh (Dewi, 2020) dan (Yunitasari \& Hanifah, 2020) dimana guru memang harus mencari cara baik berupa model maupun media yang bisa digunakan agar siswa dapat tetap melaksanakan pembelajaran. Maka penulis mengadakan penelitian Tindakan kelas dengan judul penerapan model discovery learning berbantuan media audio visual dapat meningkatkan keaktifan dan hasil belajar ipa pada siswa kelas 4 SDN 2 Penadaran. Terdapat penelitian yang dilakukan oleh (Nindya, 2018) yaitu discovery learning dapat meningkatkan keaktifan dan hasil belajar matematika. Adapun berbeda pada penelitian ini yaitu meningkatkan keaktifan dan hasil belajar IPA dengan menerapkan model discovery learning berbantuan media audio visual. Penulis berharap dengan menerapkan model ini dan siswa dapat termotivasi mengikuti pelajaran yang nantinya akan berimbas pada hasil belajar siswa sekolah dasar.

\section{METODE}

Penelitian ini menggunakan penelitian tindakan kelas (PTK) atau sering disebut dengan CAR (Classroom Action Reaserch). Peneliti menggunakan 3 tahapan pelaksanaan penelitian Tindakan kelas ini dari Kemis and Mc Taggart yaitu perencanaan, pelaksanaan, pengamatan dan refleksi.

Adapun Subjek Penelitian ini adalah siswa SDN 2 Penadaran Kelas IV Tahun Pelajaran 2020-2021 yang berlokasi di desa Penadaran, Kecamatan Gubug, Kabupaten Grobogan. Jumlah siswa yang menjadi subjek penelitian berjumlah 26 orang terdiri dari 14 laki-laki dan 12 orang perempuan. Adapun mata pelajaran yang diteliti adalah pelajaran IPA dengan kompetensi dasar mengidentifikasi macam-macam gaya, antara lain: gaya otot, gaya listrik, gaya magnet, gaya gravitasi, dan gaya gesekan dan mendemonstrasikan manfaat gaya dalam kehidupan sehari-hari, misalnya gaya otot, gaya listrik, gaya magnet, gaya gravitasi, dan gaya gesekan. yang ada dalam Tema 7 Indahnya Keragaman di Negeriku. Waktu Penelitian adalah 1 Februari sampai dengan 14 Februari 2021.

Data yang dikumpulkan dalam penelitian ini meliputi skor tes dengan bentuk pilihan ganda pada akhir setiap siklus, objektif, skor bertanya dan menjawab siswa, dan catatan lapangan yang berkaitan dengan aktivitas siswa dalam proses pembelajaran. anlisis data yang digunakan dalam penelitian ini adalah Analysis Interactive Model dari Miles dan Huberman, yang membagi langkah-langkah dalam kegiatan analisis data dengan beberapa bagian yaitu pengumpulan data (data collection), reduksi data (data reduction), penyajian data (data display), dan penarikan kesimpulan atau verifikasi (conclutions).

\section{HASIL DAN PEMBAHASAN}

Berdasarkan hasil observasi keaktifan siswa dalam pembelajaran IPA masih perlu ditingkatkan. Keaktifan siswa saat pembelajaran IPA masih cenderung rendah. Siswa kurang aktif dalam mengikuti pembelajaran, tidak ada interaksi antara guru dengan siswa, sebagian siswa hanya mendengarkan dan memperhatikan guru, siswa tidak merespon pertanyaan guru.

Peneliti menerapkan model pembelajaran discovery dengan menggunakan sebuah media video yang membantu siswa dalam menemukan sebuah konsep. Tahap-tahap pembelajaran Discovery Learning yaitu 1) menjelaskan tujuan/mempersiapkan siswa, 2) orientasi siswa pada masalah, 3) merumuskan hipotesis, 4) 
melakukan kegiatan penemuan, 5) mempresentasikan hasil kegiatan penemuan, 6) mengevaluasi kegiatan penemuan.

Pelaksanaan tindakan pada penelitian ini dilaksankan dalam 2 siklus. Siklus pertama dilaksanakan dalam 2 pertemuan, dan siklus ke dua dilaksanakan dalam 2 pertemuan. Hasil penelitian dari pra siklus ke siklus I mengalami peningkatan. Pada siklus I, siswa belum terbiasa belajar dengan model pembelajaran discovery learning. Pada siklus II peneliti melakukan perbaikan terhadap permasalahan yang timbul pada siklus 1 sehingga keaktifan dan hasil belajar siswa dalam mata pelajaran matematika semakin meningkat. Hasil observasi keaktifan belajar

Tabel 1. Hasil Observasi Keaktifan Belajar Siswa

\begin{tabular}{cccc}
\hline No & Siklus ke- & \multicolumn{2}{c}{ Ketuntasan } \\
\cline { 3 - 4 } & & Jumlah Siswa & Presentase \\
\hline 1. & Pra Siklus & 9 & $34 \%$ \\
\hline 2. & Siklus I & 18 & $69 \%$ \\
\hline 3. & Siklus II & 22 & $84 \%$
\end{tabular}

Berdasarkan tabel 1 peningkatan ketuntasan keaktifan siswa dalam pembelajaran disajikan dalam diagram berikut.

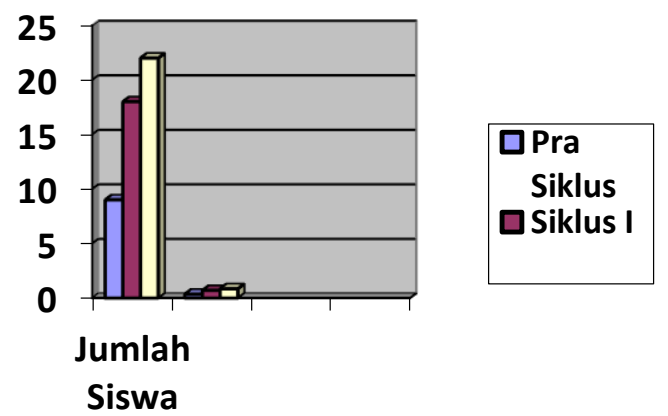

Gambar 1. Diagram Presentase Keaktifan Siswa Tiap Siklus

Berdasarkan gambar 1. Dapat dilihat bahwa persentase keaktifan siswa mengalami peningkatan dari pra siklus sebesar 34\% meningkat menjadi $69 \%$ pada siklus I. Pada siklus II terjadi peningkatan menjadi $84 \%$. Peningkatan persentase keaktifan belajar siswa pada siklus II menunjukkan bahwa indikator keberhasilan penelitian telah tercapai yaitu rata-rata keaktifan belajar siswa meningkat $10 \%$ pada siklus I ke siklus berikutnya, dan minimal 70\% siswa melakukan aktivitas sesuai indikator lembar observasi.

Hasil belajar dapat diartikan sebagai tingkat keberhasilan siswa dalam mempelajari materi pelajaran yang dinyatakan dalam skor hasil tes. Untuk mengetahui hasil belajar pada penelitian menggunakan tes. Tes dilakukan disetiap akhir siklus. Nilai rata-rata tes hasil belajar siswa dan persentase siswa yang memenuhi KKM dapat dilihat pada tabel berikut.

Tabel 2. Nilai Rata-rata dan presentase ketuntasan belajar siswa

\begin{tabular}{cccc}
\hline No. & Pelaksanaan & $\begin{array}{c}\text { Nilai Rata-rata } \\
\text { Siswa }\end{array}$ & $\begin{array}{c}\text { Presentase } \\
\text { Ketuntasan Siswa }\end{array}$ \\
\hline 1. & Pra Siklus & 50,38 & $23 \%$ \\
\hline 2. & Siklus I & 66,92 & $57 \%$ \\
\hline 3. & Siklus II & 78,46 & $84,6 \%$
\end{tabular}


Berikut adalah diagram peningkatan nilai rata-rata siswa pada setiap siklus.

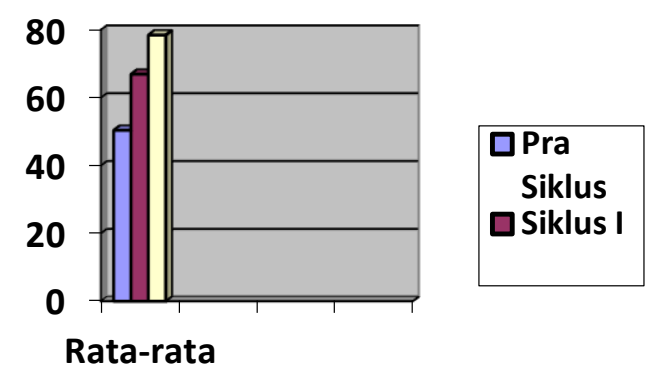

Gambar 2. Nilai rata-rata siswa per-siklus

Selain nilai rata-rata siswa tiap siklus meningkat, siswa yang mencapai KKM juga meningkat. KKM yang ditetapkan adalah 64. Berikut ini diagram persentase siswa yang mencapai KKM pada setiap siklus.

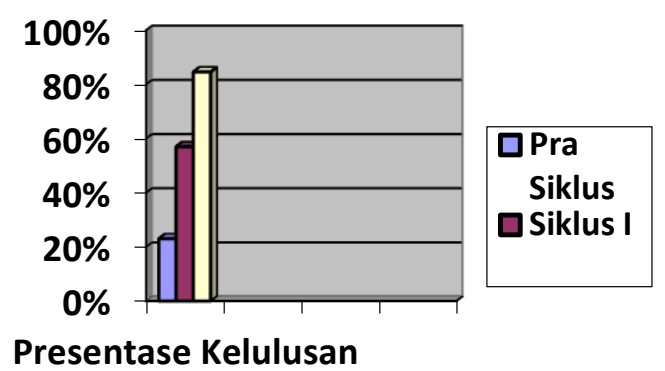

Gambar 3. Presentase Ketuntasan Hasil belajar Siswa

Berdasarkan tabel 2, dan gambar 2 dan 3, dapat diketahui bahwa hasil belajar matematika siswa kelas IV SDN 2 Penadaran mengalami peningkatan dari pra siklus, siklus I, dan siklus II. Nilai rata-rata siswa pra siklus sebesar 50,38 meningkat menjadi 66, 92 pada siklus I. Pada siklus II, nilai rata-rata siswa meningkat 78,46. Persentase siswa yang memenuhi KKM pada pra siklus sebesar 23\% atau 6 dari 26 siswa. Pada siklus I, persentase siswa yang memenuhi KKM sebesar 57\% atau 15 dari 26 siswa. Pada siklus II, persentase siswa yang memenuhi KKM kembali meningkat menjadi 84,6\% atau 22 dari 26 siswa. Terdapat 4 siswa yang nilainya belum memenuhi KKM hal tersebut dipengaruhi oleh faktor kecerdasan dan sikap siswa dalam mengikuti proses pembelajaran melalui model pembelajaran discovery. Namun, peningkatan hasil belajar siswa telah mencapai indikator keberhasilan, yaitu minimal 70\% siswa telah mencapai KKM ( $\geq 64)$ dan adanya peningkatan nilai rata-rata tes siswa dari siklus ke siklus berikutnya sebesar $10 \%$. Hasil penelitian ini sejalan dengan penelitian (Sispariyanto et al., 2019) dan (Nindya, 2018) bahwa discovery learning dapat meningkatkan keaktifan dan hasil belajar siswa sekolah dasar. Sejalan juga dengan penelitian (Syupriyanti1 et al., 2019) bahwa audio visual dapat meningkatkan hasil belajar siswa, dimana siswa juga bisa dapat lebih interaktif dalam pembelajaran.

\section{KESIMPULAN}

Berdasarkan hasil penelitian dan pembahasan, maka dapat disimpulkan peningkatan keaktifan siswa dapat dilihat dari rata-rata keaktifan tiap siklus. Pada siklus I keaktifan siswa sebesar 69\%. Pada siklus II, keaktifan siswa kembali meningkat menjadi $84 \%$. Peningkatan rata-rata keaktifan siswa dari siklus I ke siklus 
776 Model Discovery Learning Berbantuan Media Audio Visual untuk Meningkatkan Keaktifan dan Hasil Belajar IPA Siswa Sekolah Dasar - Lysa Amorita Rachmawati , Henny Dewi Koeswanti, Tri Sadono DOI: https://doi.org/10.31004/edukatif.v3i3.394

II adalah 26\%. Dengan demikian dapat disimpulkan bahwa model pembelajaran discovery dapat meningkatkan keaktifan siswa kelas IV SDN 2 Penadaran dalam mata pelajaran IPA.

\section{UCAPAN TERIMA KASIH}

Penulis mengucapkan terimakasih kepada Allah SWT yang telah meridhoi dalam penulisan penelitian ini. Kepada Dr. Henny Dewi Koeswanti, M.Pd., Tri Sadono, S.Pd., M.Pd, H. Priyono, S.Ag dan peserta didik kelas IV SDN 2 Penadaran yang telah membantu sehingga penulis dapat menyelesaikan penelitian ini.

\section{DAFTAR PUSTAKA}

Annurahman. (2010). Belajar dan Pembelajaran (Alfabeta (ed.)). Alfabeta.

Artini, Y. (2016). Penerapan Strategi TTW Untuk Meningkatkan Keaktifan Dan Keterampilan Berbicara Dalam Muatan Materi Bahasa Indonesia. Mimbar PGSD Undiksha, 4(1), 2-5.

Dewi, W. A. F. (2020). Dampak COVID-19 terhadap Implementasi Pembelajaran Daring di Sekolah Dasar. Edukatif: Jurnal Ilmu Pendidikan, 2(1), 55-61. https://doi.org/10.31004/edukatif.v2i1.89

Hamdani. (2011). Strategi Belajar Mengajar. CV. Pustaka Setia.

Heruman. (2012). Model Pembelajaran Matematika. Remaja Rosdakarya.

Isnaeni, R., Radia, E. H., Guru, P., Dasar, S., Kristen, U., \& Wacana, S. (2021). EDUKATIF : JURNAL ILMU PENDIDIKAN Meta-Analisis Pengaruh Penggunaan Media Audio Visual Terhadap Hasil Belajar IPS Siswa di Sekolah Dasar Abstrak. 3(2), 304-313.

Mawardi, M. (2014). Pemberlakuan Kurikulum Sd/Mi Tahun 2013 Dan Implikasinya Terhadap Upaya Memperbaiki Proses Pembelajaran Melalui Ptk. Scholaria: Jurnal Pendidikan Dan Kebudayaan, 4(3), 107. https://doi.org/10.24246/j.scholaria.2014.v4.i3.p107-121

Nindya, E. (2018). Peningkatan Keaktifan Dan Hasil Belajar Melalui Model Pembelajaran Discovery. Jurnal Pendidikan Ke SD-An, 4(2).

Pratiwi, D. I. (2021). EDUKATIF : JURNAL ILMU PENDIDIKAN Utilization of Information Technology during the Covid- 19 pandemic : Student 's Perception of Online Lectures Abstrak. 3(2), 447-455.

Pratiwi, S. I., Guru, P., Dasar, S., Kristen, U., \& Wacana, S. (2021). EDUKATIF : JURNAL ILMU PENDIDIKAN Pengembangan Bahan Ajar Tematik Berbasis Website untuk Peserta Didik di Sekolah Dasar Abstrak. 3(2), 333-340.

Shoimin, aris. (2014). Model Pembelajaran Inovatif Dalam Kurikulum 2013 (AR-ruz media (ed.)). AR-ruz media.

Sispariyanto, E., Relmasira, S., \& Hardini, A. (2019). UPAYA MENINGKATKAN KEAKTIFAN DAN HASIL BELAJAR IPA MELALUI MODEL DISCOVERY LEARNING DI KELAS IV SD. Jurnal Cakrawala Pendas, 5. https://doi.org/10.31949/jcp.v5i2.1333

Syupriyanti1, L., Firman2, \& Neviyarni3. (2019). PENGARUH MEDIA AUDIO VISUAL INTERAKTIF MENGGUNAKAN PENDEKATAN CTL DALAM PEMBELAJARAN TEMATIK TERPADU TERHADAP HASIL BELAJAR DAN MOTIVASI SISWA DI SEKOLAH DASAR. EDUKATIF: JURNAL ILMU PENDIDIKAN, 1(3), 237-243.

Wahyuningtyas, R., \& Sulasmono, B. S. (2020). Pentingnya Media dalam Pembelajaran Guna Meningkatkan Hasil Belajar di Sekolah Dasar. Edukatif: Jurnal Ilmu Pendidikan, 2(1), 23-27. https://doi.org/10.31004/edukatif.v2i1.77

Yunitasari, R., \& Hanifah, U. (2020). Pengaruh Pembelajaran Daring terhadap Minat Belajar Siswa pada Masa COVID 19. Edukatif: Jurnal Ilmu Pendidikan, 2(3), 232-243. https://doi.org/10.31004/edukatif.v2i3.142 
777 Model Discovery Learning Berbantuan Media Audio Visual untuk Meningkatkan Keaktifan dan Hasil Belajar IPA Siswa Sekolah Dasar - Lysa Amorita Rachmawati , Henny Dewi Koeswanti, Tri Sadono DOI: https://doi.org/10.31004/edukatif.v3i3.394 